\title{
Are NLR Rate and MPV Values Useful in Predicting Malignancy in Follicular Neoplasia, Atypia of Undetermined Significance and Suspicious Cytology? \\ NLR Oranı ve MPV Değeri Foliküler Neoplazi, Önemi Belirsiz Atipi ve Kuşkulu Sitolojide Maligniteyi Öngörmede Yararlı mıdır?
}

\author{
(1) Murat Doğan1, (1) Aykut Soyder2 \\ ${ }^{1}$ Adnan Mendres University, Department of Otorhinolaryngology, Aydın, Turkey \\ ${ }^{2}$ Adnan Mendres University, Department of General Surgery, Aydın, Turkey
}

\section{Abstract}

Objectives: Neutrophil-to-lymphocyte ratio (NLR), an indicator of systemic inflammation, and mean platelet volume (MPV) have been found to be associated with carcinogenesis in many studies. The aim of this study was to investigate the predictive values of these two parameters in detecting thyroid malignancy.

Materials and Methods: Patients who were reported to have atypia of undetermined significance, follicular neoplasia and suspected cytology as a result of thyroid fine needle aspiration biopsy (FNAB) in a tertiary health care facility between January 2010 and December 2017 and who had undergone total thyroidectomy or hemithyroidectomy due to this were evaluated. The data of 225 patients were retrospectively reviewed, and 144 patients (29 females/115 males) were included in the study.

Results: When patients found to be malignant and benign as a result of the pathology results were compared, preoperative NLR values were detected to be statistically significant in malignant patients $(p=0.002)$. Preoperative MPV values were found to be statistically insignificant. When compared in terms of FNAB groups, we found a significance only in suspicious cytology ( $p=0.001)$ but found no significance in the other groups. Conclusion: NLR may be useful in the differentiation of benign and malignant diseases but still cannot provide clear data for predicting malignancy between FNAB groups.

Key Words: Neutrophil-to-Lymphocyte Ratio, Thyroid Surgery, Mean Platelet Volume

\section{Öz}

Amaç: Sistemik enflamasyonun bir göstergesi olan nötrofil-lenfosit oranı (NLR) ve ortalama trombosit hacmi (MPV) birçok çalışmada karsinogenez ile ilişkili bulunmuştur. Bu çalışmanın amaç bu iki parametrenin tiroit malignitesini saptamadaki prediktif değerlerini araştırmaktı.

Gereç ve Yöntem: Üçüncü basamak bir sağlık kuruluşunda Ocak 2010 ile Aralık 2017 tarihleri arasında tiroit ince iğne aspirasyon biyopsisi (iïAB) sonucu önemi belirsiz atipi, foliküler neoplazi, kuşkulu sitoloji raporlanan ve bu nedenle total tiroidektomi ya da hemitiroidektomi uygulanan hastaların incelendi. 225 hastanın verileri retrospektif olarak tarandı ve 144 hasta (29 kadın/115 erkek) çalışmaya dahil edildi.

Bulgular: Preoperatif NLR değerleri kesin patoloji sonucu malign gelen hastalar ile benign gelenler arasında kıyas yapıldığında malign olanlarda istatistiksel olarak anlamlı saptandı $(p=0,002)$. Preoperatif MPV değerleri ise istatistiksel olarak anlamsız bulundu. iiAB guruplarına göre kıyas yapıldığında ise sadece kuşkulu sitolojide anlamlılık saptadık $(p=0,001)$, diğer guruplarda anlamlılık saptamadık.

Sonuç: NLR benign ve malign hastalık ayrımında faydalı olabilmektedir fakat IiAB gurupları arasında maligniteyi öngörmede bize hala net bir veri sunamamaktadır

Anahtar Kelimeler: Nötrofil Lenfosit Oranı, Tiroit Cerrahisi, Ortalama Trombosit Hacmi

Address for Correspondence/Yazışma Adresi: Dr. Lctr. Murat Doğan

Adnan Mendres University, Department of Otorhinolaryngology, Aydın, Turkey

E-mail: mudogan40@gmail.com ORCID: orcid.org/0000-0002-7551-778X

Received/Geliş: 22.07.2019 Accepted/Kabul: 11.03.2020

๑Copyright 2020 Ankara University Faculty of Medicine

Journal of Ankara University Faculty of Medicine is published by Galenos Publishing House.

All content are under CC BY-NC-ND license. 


\section{Introduction}

Thyroid cancers are the most common endocrine malignancies and present with thyroid nodules (1). Thyroid gland nodules are common lesions detected in at least $50 \%$ of patients undergoing neck ultrasonography (2). Since thyroid nodules can be a precursor of malignancy, it is important to define their nature correctly (3). There are studies reporting that thyroid cancer is closely associated with inflammation and thyroid cancer is more common in patients with thyroiditis $(4,5)$.

Inflammatory processes and immune system dysfunctions are known to be predisposing factors in the development of malignancy. Inflammation plays a role in many complex events such as cancer development, tumor progression, angiogenesis and metastasis (6). In many cancers, hematological parameters, especially neutrophil-to-lymphocyte ratio (NLR), have been shown to have a prognostic value as an answer to systemic inflammation (7). Among the many histopathological and immunochemical markers used in predicting malignancy, the use of NLR is increasing as it is fast, cheap, easy to detect and is frequently used in daily practice. As a result of these studies, it has been reported that it may be used to identify patients at risk in terms of cancer development (8).

Seretis et al. (9) and Han et al. (10) stated that preoperative measured NLR was increased in patients with papillary cancer. Liu et al. (2) found a significant relationship between tumor diameter and NLR but did not find a significant relationship between NLR and nodules' malign characteristics.

Platelets play a versatile role in cancer pathogenesis and inflammatory processes (11). There is positive correlation between increased platelet size and increased enzymatic and metabolic activities of platelets (12). It has been shown in previous studies that mean platelet volume (MPV) increases in cancer patients (13-15). Baldane et al. (16) showed in their study that MPV value was significantly higher in papillary thyroid cancer patients compared to the benign diseases and control groups.

Performing fine needle aspiration biopsy (FNAB) in thyroid nodules is one of the gold standard tests in the evaluation of thyroid nodules. However, FNAB may still fall short in detecting malignancy $(17,18)$. Therefore, unnecessary thyroidectomy can be performed on benign diseases. There is still a need for easy and fast methods for predicting thyroid malignancies to prevent morbidities related to surgeries.

The aim of our study was to answer the question of whether preoperative NLR and MPV values could be used as biomarkers in predicting thyroid malignancy. For this purpose, the preoperative FNAB histologic evaluations and preoperative NLR and MPV values of patients diagnosed with thyroid malignancy by thyroidectomy (atypia of undetermined significance, follicular neoplasia/Hurthle cell neoplasia, suspicious cytology) were examined.

\section{Materials and Methods}

Adnan Menderes University Ethical Committee and Institutional Review Board approved the study design (decision number: 2018/1355). The data of 225 patients who had undergone total thyroidectomy or hemithyroidectomy in otorhinolaryngology and general surgery clinics between January 2010 and December 2017 due to atypia of undetermined significance, follicular neoplasia and suspicious cytology as a result of thyroid FNAB retrospectively evaluated. Patients who were under 18 years of age, who had any hematological disease, chronic inflammatory disease, liver/renal failure, autoimmune disease, history of malignancy undergone myocardial infarction within the last six months, abnormal thyroid stimulating hormone levels and who have used steroid within the last three months were not included in the study. Eighty-one patients who did not meet the aforementioned criteria were excluded. The data of 144 patients in total were evaluated and presented in this study. The demographic data (age, gender, body mass index (BMI) and comorbidities), laboratory results (neutrophil, platelet, lymphocyte, MPV). Histopathological evaluation reports of FNAB of nodule and postoperative final pathology diagnoses of each patient were documented. Tyhroid nodule size which fine nedddle aspiration biopsy taken was noted. The patients were divided into two groups as benign and malignant according to postoperative final pathologic diagnosis. Automatic hematologic analyzer (Mindray BC6800, China) was used in determining preoperative NLR and MPV values.

\section{Statistical Analysis}

The Kolmogorov-Smirnov test was used to assess the normality of numeric variables. For numeric variables with normal distribution, comparison between two groups was made by the independent sample t-test, and descriptive statistics are presented as mean \pm standard deviation. For numeric variables without normal distribution, comparison between two groups was made by the Mann-Whitney $\mathrm{U}$ test, and descriptive statistics are presented as median (25-75 percentiles). To analyze the categorical data, a chi-squared test was used, and descriptive statistics are presented as frequency. $p<0.05$ was considered statistically significant.

\section{Results}

There was no significant difference between the groups in terms of mean age and intragroup gender distribution (Table 
1). No significant difference was detected between the final pathologic diagnosis (benign and malign) and MPV values, but a significant difference was detected in terms of NLR values $(p=0.002)$ (Table 1). The BMI values were not significantly different between benign and malign groups (Table 1). The mean size of all biopsied tyhroid nodules was $19.2 \pm 11.1 \mathrm{~mm}$. There were no significant differences was found in nodule size between malign $(19.7 \pm 12.1 \mathrm{~mm})$ and benign $(19.1 \pm 11.3 \mathrm{~mm})$ nodules ( $p=0.452$ ). The patients were divided into three groups according to the FNAB reports (AUS, FN and SC), and these three groups were compared in terms of NLR values. There was no statistically significant difference between these sub-groups' NLR values except for suspicious cytology group (Figure 1). NLR was statistically significantly higher in patients with suspicious FNAB cytology report. ( $p=0.001)$ (Table 2$)$.

In the analysis of MPV values, there was no significant difference between the groups reported as benign and malignant as a result of the final pathology. When the patients were divided into three groups according to their FNAB results (AUS, FN and SC) and the groups were compared in terms of MPV values, there was no statistically significant difference between the three groups (Table 2).

\begin{tabular}{|c|c|c|c|}
\hline & Benign $(n=83)$ & Malignant $(n=61)$ & p \\
\hline Age & $54.32 \pm 11.25$ & $50.3 \pm 16.06$ & 0.096 \\
\hline Gender (F/M) & $19 / 64$ & $10 / 51$ & 0.453 \\
\hline NLR & $1.86(1.46-2.22)$ & $2.1(1.75-2.7)$ & 0.002 \\
\hline MPV & $10.2 \pm 1.16$ & $10.1 \pm 1.17$ & 0.645 \\
\hline BMI $\left(\mathrm{kg} / \mathrm{m}^{2}\right)$ & $25.7 \pm 3.9$ & $26.1 \pm 4.3$ & 0.741 \\
\hline
\end{tabular}

F: female, M: male, NLR: neutrophil-to-lymphocyte ratio, MPV: Mean Platelet Volume, BMI: Body mass index, $n$ : Number

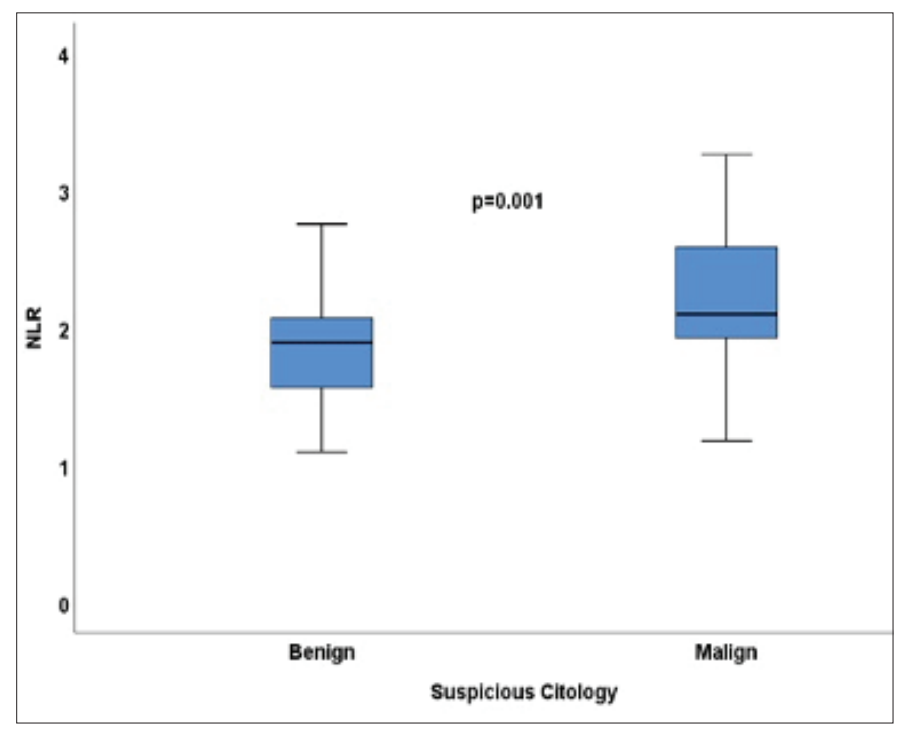

Figure 1: Suspicious citology NLR (insignificant difference $p=0.001$ ). NLR: neutrophil-to-lymphocyte ratio

\begin{tabular}{lllll}
\multicolumn{5}{c}{ Table 2: NLR and MPV of patients according to FNAB groups } \\
\multirow{4}{*}{ AUS $^{\beta}$} & Variables & Benign $^{\alpha}$ & Malignant & p \\
& MPV & $10.1 \pm 0.99$ & $10.25 \pm 1.36$ & 0.704 \\
& NLR & $1.86(1.55-2.42)$ & $1.93(1.23-3.23)$ & 0.787 \\
FN $^{\beta}$ & MPV & $9.77 \pm 0.99$ & $9.9 \pm 1.04$ & 0.705 \\
& NLR & $1.56(1.37-2.16)$ & $2.02(1.5-2.63)$ & 0.196 \\
$\mathrm{SC}^{\beta}$ & MPV & $10.52 \pm 1.31$ & $10.13 \pm 1.18$ & 0.207 \\
& NLR & $1.89(1.6-2.08)$ & $2.1(1.92-2.71)$ & 0.001
\end{tabular}

Significant $p$ values are written in bold.

AUS: Atypia of undetermined significance, FN: Follicular neoplasia, SC: Suspicious cytology

$\beta$ : Preoperative FNAB results, $\alpha$ : Postoperative final pathology result

\section{Discussion}

As a result of our study, MPV and NLR values were not found predictively valuable for the for malignancy in patients whose thyroid nodule FNAB reported as AUS, FN, SC. However, it was found that NLR value could be useful in predicting malignancy in those with suspicious cytology results in FNAB $(p=0.001)$.

The common use of ultrasonography in daily clinical practice has led to more frequent detection of thyroid nodules. Thus, thyroid cancers are detected more frequently, and the prevalence of interventions increases (19). FNAB is the standard method for evaluating the cellular properties of thyroid nodules $(20,21)$. Clinical, ultrasonographic and cytological evaluations are performed to predict malignancy as a whole; however, despite all these evaluations, they may still fall short in presenting malignancy clearly. According to the American Thyroid Association criteria, although properties that increase the suspicion of malignancy such as solidity, hypoechoicity, microcalcification, border irregularity and length/width ratio have been reported to increase in ultrasonographic evaluation of nodules, these parameters are not always clear in clinical practice. There is a need for other parameters that can be applied easily and inexpensively in daily practice and that may provide additional contribution to the detection of malignancy in thyroid nodules. For this purpose, we planned our study by assuming that NLR and MPV values may be used as predictive values in the determination of malignancy. Similar to study of Salmaslioglu et al. (22) in our study no significant relationship was determined between nodule size and malign pathological diagnosis.

In their study, Kocer et al. (23) compared patients with papillary thyroid cancer, patients with papillary thyroid cancer accompanied by lymphocytic thyroiditis and those with benign multinodular goiter and detected NLR to be significantly higher. In the study of Seretis et al. (9), NLR was detected to be significantly higher in patients with papillary microcarcinoma compared to those with benign goiter. Liu et al. (2) found that 
tumor diameter and NLR in recurrences were significantly high. In their study, Lang et al. (24) found that increased NLR was significantly correlated with tumor diameter and stage. In the study of Kim et al. (25), preoperative NLR was found to be statistically significant for patients with a tumor diameter above $1 \mathrm{~cm}$ and those with lymphovascular invasion. In their study, Manatakis et al. (26) found that high NLR was associated with aggressive tumors (extrathyroidal invasion, lymph node metastasis, bilaterality, multifocality) and poor histopathological type, but no significant relationship was found in terms of tumor diameter and stage. Gong et al. (27) found preoperative high NLR to be positively correlated with tumor diameter, lymph node metastasis and multifocality. Seretis et al. (9) detected a statistically significant difference between benign goiter and papillary microcarcinoma and papillary carcinoma in terms of preoperative NLR and also a significant difference between the control group and the papillary cancer and papillary microcarcinoma groups. In a meta-analysis of Templeton et al. (28) on over 40000 patients with many solid tumors, they showed that high NLR was associated with poor survival, in correlation with these studies. We found in our study that preoperative NLR was statistically significantly higher in malignant patients compared to those who had benign results in the final pathology, similar to these studies. In addition, when preoperative NLR was compared between the FNAB groups, it was found to be statistically significant in suspicious cytology. As seen in all these studies, high NLR has been associated with many factors (tumor size, lymph node metastasis, multifocality, lymphovascular invasion, tumor stage, etc.). Again, in many studies, it has been found significant in the differentiation of benign and malignant diseases, similar to our study. While NLR values are found to be associated with prognosis and survival in many tumors, they also contribute to predicting malignancy. It contributed to this in our study, and it may also contribute to the prediction of malignancy in cases where a clear malignancy picture such as suspicious cytology cannot be drawn, on the contrary to the other studies.

In studies on patients with papillary thyroid cancer, NLR was found to be significantly high, while there is no determined cutoff value. In their studies, Liu (29) found it as 1.94, Seretis (9) as 2.5, Kim (25) as 1.74, Lang (24) as 2.68, Kocer (23) as 2.57, Yaylacı as 1.99, Manatakis (26) as 2.44 and Gong (27) as 2. As can be seen, the values found to be significant in the studies are all different from each other. The difference in these rates shows us the difficulty, inadequacy and limitation of use in finding and evaluating the baseline value.

In a meta-analysis by Liu et al. (29) no significant difference was detected between differentiated thyroid cancer and benign goiter in terms of NLR. Soyder et al. (30) found no statistically significant difference in NLR when they compared postoperative pathologies in patients with follicular neoplasia results in FNAB. Liu et al. (2) detected no significant difference between follicular adenoma and papillary cancer, and they could not find a significant difference between tumor stage and NLR, either. In the study of Cho et al. (31) on 3870 benign and malignant patients, no significant difference was found between malignant tumor types or between benign and malignant tumors.

Considering all these studies, we could find those that do or do not support our study. This shows that there is still no clear result on the topic. When thyroid malignant tumors are evaluated, NLR can be significant in terms of tumor malignancy, diameter, lymphovascular invasion and lymph node involvement. As can be seen, NLR may be categorized based on certain factors between patients with malignant diagnosis, but it may be insufficient in predicting the previous stage of final pathology, malignancy. In our study, the significant result we found in suspicious cytology could help us at this point. While we could detect a significant difference in differentiating benign and malignant diseases, it still could not present us a certain cut-off value.

In the pathogenesis of platelet cancer, inflammatory cytokines play an important role in angiogenesis, metastasis, progression and proliferation through vascular endothelial growth factor and other growth factors $(32,33)$. MPV shows the reflex activity of thrombocyte. In the study of Tuncel et al. (34) on 148 patients with colorectal cancer, MPV values were found to be significantly higher in patients with metastatic colorectal cancer compared to those who did not develop metastasis. Mutlu et al. (35) administered the anti-angiogenic agent bevacizumab to patients with metastatic colon cancer and determined that the MPV levels of the patients decreased significantly. In the study of Krajewska and Jarzab (36) on patients with advanced thyroid cancer based on this study, anti-angiogenic drug activity was investigated. Lian et al. (37) found MPV levels to be decreased after chemotherapy in unresectable gastric cancers and reported that MPV could be used in treatment response and follow-up. Kemal et al. (14) found MPV to be significantly higher in patients with ovarian cancer compared to the control group; KIlınçalp et al. (38) in patients with gastric cancer and Gu et al. (39) in patients with breast cancer. In addition, these studies showed that postoperative MPV values decreased significantly compared to preoperative values.

Eryilmaz et al. (40) found that MPV was significantly higher in patients with head and neck cancers compared to the control group. Baldane et al. (16) found that preoperative MPV was significantly higher in patients with papillary thyroid cancer compared to those with benign diseases and that MPV level decreased after the operation, but no significant difference was detected between the benign diseases and control groups. 
On the contrary to these studies, there are studies where preoperative MPV value was detected to be low. Kumagai et al. (41) found that MPV values were significantly lower in patients with lung cancer compared to the control group; Aksoy et al. (42) obtained similar results in patients with solid tumors with bone metastasis and Oncel et al. (43) in patients with lung cancer. Dincel et al. (44) could not find any significance between nodular goiter and papillary thyroid carcinoma in terms of MPV. In our study, there was no significant difference between the patients with malignant and benign pathologies in terms of $M P V$, and there was no significant difference between the FNAB groups when they were evaluated separately. While studies have suggested that MPV may be useful in predicting malignancy or in showing response to treatment, we did not obtain such results in our study, and it could not predict malignancy.

\section{Study Limitations}

Our study had several limitations. The retrospective study design and the small sample size could be considered among these. Another limitation was that we could not offer any certain cut-off value. More accurate information can be obtained with multicenter studies including all FNAB groups prospectively. When the literature is examined, there is no consensus on whether NLR and MPV values show significant differences in thyroid malignancies. Therefore, for a clearer understanding of the topic, prospective clinical studies with higher numbers of patients are needed. MPV and NLR may be affected many factors such as blood sugar and body mass index. Since the blood glucose levels of the patients during the preoperative evaluation were measured as both fasting and postprandial. the blood glucose level could not be included in the study because it was not obtained as standardized. The BMI values were gathered and analysed. However, there was not significantly different between benign and malign groups in terms of BMI values.

Our study is the first study to investigate the predictive value of preoperative MPV value on malignancy between FNAB groups (AUS, FN, SC) in patients with malignant diagnoses in final pathology. Similarly, it is also the first study to investigate the predictive value of preoperative NLR on suspicious cytology and atypia of undetermined significance between FNAB groups.

\section{Conclusion}

There is a need for increased markers that could be used in predicting thyroid malignancies, making better follow-up or surgery decisions, preventing unnecessary surgeries and selecting the appropriate types of surgeries. When we evaluated the results of our study, we found that MPV values were not yet useful for this purpose. NLR values, however, are significant in differentiating benign and malignant patient groups. In addition, while NLR was found to be significant in suspicious cytology, it was not found to be useful in the other groups. We believe that further studies on the topic are needed.

\section{Ethics}

Ethics Committee Approval: Adnan Menderes University Ethical Board approved this study (2018/1355).

Informed Consent: Retrospective study.

Peer-review: Externally and internally peer-reviewed.

\section{Authorship Contributions}

Surgical and Medical Practices: M.D., A.S., Concept: M.D., A.S., Design: M.D., A.S., Data Collection or Processing: M.D., A.S., Analysis or Interpretation: M.D., A.S., Literature Search: M.D., A.S., Writing: M.D., A.S.

Conflict of Interest: No conflict of interest was declared by the authors.

Financial Disclosure: The authors declared that this study received no financial support.

\section{References}

1. Liu CL, Lee JJ, Liu TP, et al. Blood neutrophil-to-lymphocyte ratio correlates with tumor size in patients with differentiated thyroid cancer. J Surg Oncol. 2013;107:493-497.

2. Luo J, McManus $\mathrm{C}$, Chen $\mathrm{H}$, et al. Are there predictors of malignancy in patients with multinodular goiter? J Surg Res. 2012;174:207-210.

3. Zhou GJ, Xiao M, Zhao LN, et al. MicroRNAs as novel biomarkers for the differentiation of malignant versus benign thyroid lesions: a meta-analysis. Genet Mol Res. 2015;14:7279-7289.

4. Guarino V, Castellone MD, Avilla E, et al. Thyroid cancer and inflammation. Mol Cell Endocrinol. 2010;321:94-102.

5. Larson SD, Jackson LN, Riall TS, et al. Increased incidence of welldifferentiated thyroid cancer associated with Hashimoto thyroiditis and the role of the PI3k/Akt pathway. J Am Coll Surg. 2007;204:764-773.

6. Moore MM, Chua W, Charles KA, et al. Inflammation and cancer: causes and consequences. Clin Pharmacol Ther. 2010;87:504-508.

7. Proctor MJ, McMillan DC, Morrison DS, et al. A derived neutrophil to lymphocyte ratio predicts survival in patients with cancer. $\mathrm{Br} J$ Cancer. 2012;107:695-699.

8. Clarke SJ, Chua W, Moore M, et al. Use of inflammatory markers to guide cancer treatment. Clin Pharmacol Ther. 2011;90:475-478.

9. Seretis C, Gourgiotis $\mathrm{S}$, Gemenetzis $\mathrm{G}$, et al. The significance of neutrophil/ lymphocyte ratio as a possible marker of underlying papillary microcarcinomas in thyroidal goiters: a pilot study. Am J Surg. 2013;205:691-696.

10. Han SW, Kang SY, Kim SK, et al. Clinical significance of blood neutrophilto-lymphocyte ratio in patients with papillary thyroid carcinoma. Korean J Endocr Surg. 2014;14:184-189.

11. Kemal Y, Yucel I, Ekiz K, et al. Elevated serum neutrophil to lymphocyte and platelet to lymphocyte ratios could be useful in lung cancer diagnosis. Asian Pac J Cancer Prev. 2014;15:2651-2654.

12. Mangalpally KK, Siqueiros-Garcia $A$, Vaduganathan $M$, et al. Platelet activation patterns in platelet size sub-populations: differential responses to aspirin in vitro. J Thrombosis Thrombolysis. 2010;30:251-262.

13. Cho SY, Yang JJ, You E, et al. Mean platelet volume/platelet count ratio in hepatocellular carcinoma. Platelets. 2013;24:375-377.

14. Kemal Y, Demirağ G, Ekiz K, et al. Mean platelet volume could be a useful biomarker for monitoring epithelial ovarian cancer. J Obstet Gynaecol. 2014;34:515-518. 
15. Kılınçalp S, Ekiz F, Başar O, et al. Mean platelet volume could be possible biomarker in early diagnosis and monitoring of gastric cancer. Platelets. 2014;25:592-594.

16. Baldane $S$, Ipekci SH, Sozen $M$, et al. Mean platelet volume could be a possible biomarker for papillary thyroid carcinomas. Asian Pac J Cancer Prev. 2015;16:2671-2674.

17. Hamberger $B$, Gharib $H$, Melton $\sqcup 3$ rd, et al. Fine-needle aspiration biopsy of thyroid nodules. Impact on thyroid practice and cost of care. Am J Med. 1982;73:381-384

18. Yassa L, Cibas ES, Benson $C B$, et al. Long-term assessment of a multidisciplinary approach to thyroid nodule diagnostic evaluation. Cancer. 2007;111:508-516.

19. Haugen BR, Alexander EK, Bible KC, et al. 2015 American thyroid association management guidelines for adult patients with thyroid nodules and differentiated thyroid cancer: the american thyroid association guidelines task force on thyroid nodules and differentiated thyroid cancer. Thyroid. 2016;26:1-133.

20. Goldstein RE, Netterville JL, Burkey B, et al. Implications of follicular neoplasms, atypia, and lesions suspicious for malignancy diagnosed by fineneedle aspiration of thyroid nodules. Ann Surg. 2002;235:656-662.

21. Ersöz C, Firat $P$, Uguz A, et al. Fine-needle aspiration cytology of solitary thyroid nodules: how far can we go in rendering differential cytologic diagnoses? Cancer. 2004;102:302-307.

22. Salmaslioğlu A, Erbil $Y$, Dural $C$, et al. Predictive value of sonographic features in preoperative evaluation of malignant thyroid nodules in a multinodular goiter. World J Surg. 2008;32:1948-1954.

23. Kocer D, Karakukcu C, Karaman H, et al. May the neutrophil/lymphocyte ratio be a predictor in the differentiation of different thyroid disorders? Asian Pac J Cancer Prev. 2015;16:3875-3879.

24. Lang $B H, N g C P, A u K B$, et al. Does preoperative neutrophil lymphocyte ratio predict risk of recurrence and occult central nodal metastasis in papillary thyroid carcinoma? World J Surg. 2014;38:2605-2612.

25. Kim SM, Kim EH, Kim BH, et al. Association of the Preoperative Neutrophilto-ymphocyte Count Ratio and Platelet-to-Lymphocyte Count Ratio with Clinicopathological Characteristics in Patients with Papillary Thyroid Cancer. Endocrinol Metab (Seoul). 2015;30:494-501.

26. Manatakis DK, Tseleni-Balafouta $S$, Balalis D, et al. Association of Baseline Neutrophil-to-Lymphocyte Ratio with Clinicopathological Characteristics of Papillary Thyroid Carcinoma. Int J Endocrinol. 2017;2017:8471235.

27. Gong W, Yang S, Yang X, et al. Blood preoperative neutrophil-to-lymphocyte ratio is correlated with TNM stage in patients with papillary thyroid cancer. Clinics (Sao Paulo). 2016;71:311-314.

28. Templeton AJ, McNamara MG, Seruga B, et al. Prognostic role of neutrophilto-lymphocyte ratio in solid tumors: a systematic review and meta-analysis. J Natl Cancer Inst. 2014;106:124.
29. Liu JF, Ba L, Lv H, et al. Association between neutrophil-to-lymphocyte ratio and differentiated thyroid cancer: a meta-analysis. Sci Rep. 2016;6:38551.

30. Soyder $A$, Ünübol $M$, Şen 0 , Özbaş $S$, et al. The predictive value of the clinical features of malignancy in cases of preoperative follicular thyroid neoplasia. Minerva Chir. 2012;67:475-480.

31. Cho JS, Park MH, Ryu YJ, et al. The neutrophil to lymphocyte ratio can discriminate anaplastic thyroid cancer against poorly or well differentiated cancer. Ann Surg Treat Res. 2015;88:187-192.

32. Kisucka J, Butterfield CE, Duda DG, et al. Platelets and platelet adhesion support angiogenesis while preventing excessive hemorrhage. Proc Nat Acad Sci U S A. 2006;103:855-860.

33. Sierko E, Wojtukiewicz MZ. Platelets and angiogenesis in malignancy. Semin Thromb Hemost. 2004;30:95-108.

34. Tuncel T, Ozgun A, Emirzeoglu L, et al. Mean platelet volume as a prognostic marker in metastatic colorectal cancer patients treated with bevacizumabcombined chemotherapy. Asian Pac J Cancer Prev. 2014;15:6421-3.

35. Mutlu $H$, Berk V, Karaca $H$, et al. Treatment regimen with bevacizumab decreases mean platelet volume in patients with metastatic colon cancer. Clin Appl Thromb Hemost. 2012;18:546-68.

36. Krajewska J, Jarzab B. Novel therapies for thyroid cancer. Expert Opin Pharmacother. 2014;15:2641-52.

37. Lian L, Xia YY, Zhou C, et al. Mean platelet volume predicts chemotherapy response and prognosis in patients with unresectable gastric cancer. Oncol Lett, 2015;10:3419-3424.

38. Kılınçalp S, Ekiz F, Başar 0 , et al. Mean platelet volume could be possible biomarker in early diagnosis and monitoring of gastric cancer. Platelets. 2014;25:592-594.

39. Gu M, Zhai Z, Huang L, et al. Pre-treatment mean platelet volume associates with worse clinicopathologic features and prognosis of patients with invasive breast cancer. Breast Cancer. 2016;23:752-760.

40. Eryilmaz A, Basal Y, Omurlu IK. Can Head and Neck Cancers Be Detected with Mean Platelet Volume? Asian Pac J Cancer Prev. 2015;16:7045-7047.

41. Kumagai S, Tokuno J, Ueda Y, et al. Prognostic significance of preoperative mean platelet volume in resected non-small-cell lung cancer. Mol Clin Oncol. 2015;3:197-201.

42. Aksoy S, Kilickap S, Hayran M, et al. Platelet size has diagnostic predictive value for bone marrow metastasis in patients with solid tumors. Int J Lab Hematol. 2008;30:214-219.

43. Oncel $M$, Kiyici $A$, Oncel $M$, et al. Evaluation of Platelet Indices in Lung Cancer Patients. Asian Pac J Cancer Prev. 2015;16:7599-7602.

44. Dincel 0, Bayraktar C. Evaluation of platelet indices as a useful marker in papillary thyroid carcinoma. Bratisl Lek Listy. 2017;118:153-155. 